\title{
Evaluation of Released Taro (Colocasia esculenta L.) Varieties at Assosa District, Western Ethiopia
}

\author{
Desta Bekele ${ }^{1, *}$, Merga Boru ${ }^{2}$ \\ ${ }^{1}$ Department of Horticulture, Assosa Agricultural Research Centre, Assosa, Ethiopia \\ ${ }^{2}$ Department of Agronomy, Assosa Agricultural Research Centre, Assosa, Ethiopia
}

Email address:

destabek.48@gmail.com (D. Bekele)

${ }^{*}$ Corresponding author

To cite this article:

Desta Bekele, Merga Boru. Evaluation of Released Taro (Colocasia esculenta L.) Varieties at Assosa District, Western Ethiopia. Ecology and Evolutionary Biology. Vol. 5, No. 3, 2020, pp. 43-46. doi: 10.11648/j.eeb.20200503.12

Received: September 1, 2020; Accepted: October 19, 2020; Published: October 27, 2020

\begin{abstract}
Taro (Colocasia esculenta L.) is a herbaceous, monocotyledonous, perennial stem root crop that is widely cultivated in tropical and sub tropical regions of the world. In Ethiopia taro is cultivated in southern, south western and western of part of the country. The title of experiment was evaluation of released taro (Colocasia esculenta L.) varieties at Assosa, Western Ethiopia. The objective was to identify adaptable, high yielding with good quality taro variety for Benishangul Gumuz region. The experiment was carried out in RCBD with three replications at Assosa Agricultural Research Center in 2016/17 cropping season. The crop was planted on a plot size of $5 \mathrm{mx} 3 \mathrm{~m}\left(15 \mathrm{~m}^{2}\right)$ with inter and intra raw spacing of $75 \mathrm{~cm}$ and $50 \mathrm{~cm}$, respectively. Data of growth performance, yield and yield components were recorded. Some parameters showed that no significance difference $(\mathrm{P}>0.05)$ among varieties in terms of corm diameter, plant height, corm length, number of corm per plant, number of corm per ha, number of cormel per ha, yield of cormel tone per ha whereas leaf number, number of suckers, weight of corm per plant, total number of yield per ha, total yield tone per hectare, corm yield per ha revealed that significance difference among varieties. The highest total yield (16.75 t/ha) per hectare was recorded in Boloso-1 variety while the lowest total yield of taro $(8.07 \mathrm{t} / \mathrm{ha}$ ) per hectare was obtained from Kiyaq variety. Boloso-1 variety was best when compared to others varieties. So, Boloso-1 variety was recommended for Assosa area followed by local variety.
\end{abstract}

Keywords: Evaluation, Taro, Varieties

\section{Introduction}

Colocasia (Colocasia esculenta also known as 'edode' or 'arvi' is a tropical tuber crop belongs to the monocotyledonous family 'Araceae' of the order Arales whose members are known as 'aroids' [1]. Taro (Colocasia esculenta (L.) Schott) is a herbaceous, monocotyledonous, perennial stem root crop that is widely cultivated in tropical and subtropical regions of the world. It is originated from tropical areas of South and Southeast Asia and the Pacific Islands [2]. Taro (Colocasia esculenta (L) is a herbaceous, monocotyledonous, perennial stem root crop that is widely cultivated in tropical and sub tropical regions of the world. It is originated from tropical areas of South and Southeast Asia and the Pacific Islands [2]. Taro belongs to genus Colocasia and family Araceae which is made up of at least 100 genera and more than 1500 species [3].

In Ethiopia taro is cultivated mostly in the high rainfall areas of South and Western parts of the country by smallholder farmers. It is mainly produced for food purpose in Ethiopia. Taro crop is cultivated to fill seasonal food gaps when other crops still in the fields because of its potential in giving reasonable yield under conditions where other crops may unable to give produce by various crop production constraints [4]. It can be grown as a root crop, as a leafy vegetable, as an ornamental and as medicinal plant and it is not only used in times of food shortage [3].

Besides, described role of taro in food security, income generation and who stated as taro corms, leaves, and petiole are rich in carbohydrate, fiber and minerals and as it has been produced in Africa by small holder farmers and plays important roles in livelihood of many poor people in less developed countries [5]. Its flour is considered good baby 
food because its starch is easily digestible; and it helps with digestive problems and supplements iron [6]. According to some authors taro starch digestibility is as high as $98 \%$ [7]. Particularly, taro is important for food security. All parts of the plant including corm, cormels, rhizome, stalk, leaves and flowers are edible contain abundant starch [8].

In Ethiopia, it has been cultivated mainly and extensively in dense populated and high rainfall areas of South, Southwest and Western parts of the country. It is cultivated because of producing reasonable amounts of yield when other crops hardly grow, resistant to disease and pests, ease of ecological adaptation and utilization of different purposes. Despite of that in Benishangul Gumuz Region there are no released taro varieties.

\subsection{Objective of study}

General objective: To familiarize farmers and beneficiaries with released taro varieties at Assosa district.

Specific Objective: The specific objective of the experiment was to select adapted, high yielding with good quality of taro variety for area of the study.

\subsection{Significance of Study}

To increase productivity and production of recently released taro variety in Assosa area.

\section{Methods and Materials}

\subsection{Description of the Study Area}

The experiment was conducted in Benishangul Gumuz Regional State, at Asossa Agricultural Research Center (AsARC) in the 2016 main cropping season under rain fed conditions. Benishangul Gumuz Regional State is geographically located at the latitude of $9^{\circ} 30^{\prime}$ to $11^{\circ} 39^{\prime \prime} \mathrm{N}$ and longitude of $34^{\circ} 20^{\prime}$ to $36^{\circ} 30^{\prime \prime} \mathrm{E}$ covering a total land area of 50,000 square kilometer. The study site is located at $10^{\circ} 02^{\prime} 05^{\prime \prime} \mathrm{N}$ latitude and $34^{\circ} 34^{\prime} 09^{\prime \prime} \mathrm{E}$ longitudes. The study area is situated east of Asossa town and west of Addis Ababa about $4 \mathrm{~km}$ and $660 \mathrm{~km}$ distance, respectively. Asossa has unimodal rainfall pattern, which starts at the end of April and extends to mid-November, with maximum rainfall received in June, July, August, September, and October. The total annual average rainfall of Asossa is $1275 \mathrm{~mm}$. The minimum and maximum temperatures are $16.75^{\circ} \mathrm{C}$ and $27.92^{\circ} \mathrm{C}$, respectively. The dominant soil type of Asossa area is Nitosols and Fluvisols with the soil $\mathrm{pH}$ ranges from 5.5 to 6.0. The crops mainly cultivated in the area are mango, sorghum, maize, finger millet and soybean [9].

\subsection{Planting Materials}

The two released upland (dry land) taro varieties (Denu and Kiyaq) were obtained from Jimma Agricultural Research Center and one recently released taro variety (Boloso -1) from Areka Agricultural Research Center in addition with the local check were evaluated using RCBD with three replications under recommended management practices.

\subsection{Experimental Design}

The experiment was laid out in RCBD with three replications. Each plot size had an area of $15 \mathrm{~m}^{2}$ and an experiment has 12 a total number of plots. Spacing between plants and rows were $50 \mathrm{~cm}$ and $75 \mathrm{~cm}$ respectively.

\subsection{Data Collection}

To evaluate the yield and yield components of taro varieties including corm diameter, corm length, plant height, number of suckers, number of corm per plant, weight of corm per plant were recorded from five randomly selected plants of the two middle rows except, number of corm per ha, weight of corm per ha, number of cormel per ha, weight of cormel per ha, total number of corm per ha and total yield of corm data were taken per plot basis as per the procedure [10].

\subsection{Data Analysis}

Collected data were subjected to analysis of variance (ANOVA) using general linear model (GLM) procedures with the help of software SAS version 9.00 [11]. Means separation for significant treatments effects was carried out using the least significant difference (LSD) test at 5\% level of significance.

\section{Results and Discussions}

\subsection{Growth Performance and Yield Components}

The results showed that there were no significance difference $(\mathrm{P}>0.05)$ among varieties in terms of corm diameter, corm length, number of corm per plant and plant height (table1). The highest weight of corm per plant was observed in Boloso-1 variety whereas the lowest weights of corm per plant were obtained in kiyaq variety. The highest weight of corm per plant was recorded from Boloso-1 variety whereas the lowest weight of corm per plant was obtained from Kiyaq variety. The variation in the size might be associated with the genetic potential of that particular genotype and environment effect. Similar variation was reported by $[12,13]$ in colocasia.

This result similar to author who reported that average weight of corm revealed that significance difference among cultivars [14]. The results of some parameters revealed that leaf number, weight of corm per plant and number of sucker were significantly $(\mathrm{P}<0.05)$ affected by different taro varieties. This variation is might be due to inherit potential of the varieties. These results are in agreement with other authors who reported that yield differences among genotypes were attributed by the inherent yield potential of genotypes $[15,16]$.

The highest number of sucker was recorded from Boloso-1 variety whereas the lowest number sucker was obtained from Kiyaq variety. This result similar author who reported that average weight of corm revealed that significance difference among cultivars [16]. Significant differences were recorded 
in number of leaf number among varieties. The highest number of leaf number (21.4) was recorded from Danu variety followed by Boloso 1 variety whereas the lowest leaf numbers (9.33) were recorded from kiyaq variety.

Table 1. Mean growth performance and yield components of released taro varieties at Assosa, Western Ethiopia.

\begin{tabular}{|c|c|c|c|c|c|c|c|}
\hline Varieties & CD (cm) & CL (cm) & PH (cm) & $\mathbf{L N}$ & NS & NCP & WCP (g/plant) \\
\hline Local & 5.6333 & 6.50 & 54.93 & $16.9 \mathrm{a}$ & $3.13 b$ & 3.6000 & $479.50 \mathrm{bc}$ \\
\hline Danu & 5.8000 & 9.10 & 48.67 & $21.4 \mathrm{a}$ & $5.00 \mathrm{a}$ & 7.2667 & $619.26 \mathrm{ab}$ \\
\hline Kiyaq & 5.7667 & 7.66 & 45.07 & $9.33 b$ & $1.93 \mathrm{~b}$ & 2.2000 & $339.12 c$ \\
\hline Bolosso & 5.33 & 7.36 & 37.27 & $20.2 \mathrm{a}$ & $6.40 \mathrm{a}$ & 7.2000 & $656.3 \mathrm{a}$ \\
\hline LSD & & & & 5.62 & 1.66 & & 163.3 \\
\hline Sig level & $\mathrm{Ns}$ & Ns & Ns & $*$ & $*$ & $\mathrm{Ns}$ & $*$ \\
\hline $\mathrm{CV} \%$ & 7.53 & 11.51 & 12.15 & 16.58 & 20.24 & 22.33 & 15.61 \\
\hline
\end{tabular}

$*=$ Significant at 5\% LSD, LSD= Least Significance Difference, $\mathrm{CV}=$ Coefficient of Variation, Ns= Non significant, $\mathrm{CD}=\mathrm{Corm}$ Diameter, CL= Corm length, $\mathrm{PH}=$ Plant Height, $\mathrm{LN}=$ Leaf Number, NS=Number of suckers, $\mathrm{NCP}=$ number of corm per plant, WCP= Weight of corm per plant.

\subsection{Yield Parameters}

The result revealed that number of corm, number and weight of cormel were not significantly $(\mathrm{P}>0.05)$ affected by varieties (Table 2).

Some parameters such as corm yield, number of corm, total number and total yield were significantly $(\mathrm{P}<0.05)$ affected by varieties (Table 2). This might be due to inherit potential of varieties. Similarly, other author also reported that corm yield was significantly varied by variety [14]. The highest yield of corm (12.74 t/ha), was recorded by Boloso-1 variety whereas lowest yield of corm (5.94 t/ha) was observed from Kiyaq variety. The highest total yield (16.75 t/ha) was recorded by Boloso-1 while the lowest total yield (8.07 t/ha) was obtained from Kiyaq variety. High total yield in Boloso-1 may be attributed to a better utilization of photosynthesis (due to maximum number of sucker and leaf number), resulting in better number corm per plant. Similar result was observed by [17].

Table 2. Mean of yield parameters of released taro varieties at Assosa, Western Ethiopia.

\begin{tabular}{|c|c|c|c|c|c|c|}
\hline Varieties & Number of Corm ha ${ }^{-1}$ & Corm Yield (t/ha) & Number of Cormel Yield ha ${ }^{-1}$ & Cormel Yield (t/ha) & TNYha $^{-1}$ & TY (t/ha) \\
\hline Local & $97778 \mathrm{ab}$ & $8.71 \mathrm{~b}$ & $246889 \mathrm{a}$ & 4.21 & $344667 a$ & $12.92 \mathrm{ab}$ \\
\hline Danu & $156297 \mathrm{a}$ & $11.33 \mathrm{ab}$ & $178518 \mathrm{ab}$ & 3.73 & $334815 \mathrm{ab}$ & $15.06 \mathrm{ab}$ \\
\hline Kiyaq & $53926 b$ & $5.94 \mathrm{c}$ & $108444 b$ & 2.14 & $162370 \mathrm{~b}$ & $8.07 \mathrm{~b}$ \\
\hline Boloso-1 & $135111 \mathrm{a}$ & $12.74 \mathrm{a}$ & $184889 \mathrm{ab}$ & 4.01 & $320000 \mathrm{ab}$ & $16.75 a$ \\
\hline LSD & 67266 & 2.68 & & & 153489 & 8.09 \\
\hline Sign level & $*$ & $*$ & Ns & Ns & $*$ & $*$ \\
\hline $\mathrm{CV}$ & 30.26 & 13.86 & 36.27 & 37.6 & 38.8 & 33.5 \\
\hline
\end{tabular}

*= Significant level at 5\% LSD, LSD $=$ Least Significance Difference, CV= Coefficient of Variation, Ns= Non significant, TNY per ha= Total Number of Yield per Ha, TY= Total Yield tone per hectare.

\section{Conclusion and Recommendation}

Three released taro varieties (Denu, Kiyaq and Boloso-1) with one local check were evaluated at Assosa Agricultural Research Center. Boloso-1 variety was recorded the highest total yield (16.75 t/ha) followed by Danu variety $(15.06 \mathrm{t} / \mathrm{ha})$ whereas Kiyaq variety gave the lowest total yield $(8.07 \mathrm{t} / \mathrm{ha})$. So, we recommended Boloso-1 variety for Assosa areas based on corm yield per ha and total taro yield per hectare.

\section{Acknowledgements}

I kindly knowledge Ethiopian Institute of Agricultural Research and Assosa Agricultural Research Center for its financial support.

\section{References}

[1] Henry, R. J. (2001). Plant genotyping: The DNA fingerprinting of plants. CAB Publishing, Southern Cross University, Australia.
[2] Jianchu X., Y. Yang, P. W. Yingdong, G. Ayad and P. B. Eyzagủirre (2001). The genetic diversity in taro (Colocasia esculenta Schott-Araceae) in China: An Ethno botanical and genetic approach Economic Botany. 55 (1), 14-31.

[3] Mandal R, Mukherjee A, Mandal N, Tarafdar J, Mukherjee A. (2013). Assessment of genetic diversity in Taro using morphometrics. Curr Agr Res J 1: 79-85.

[4] Tewodros M, Getachew W, and Asfaw K. (2013). Genetic diversity of Taro (Colocasia esculenta (L.) Schott) genotypes in Ethiopia based on agronomic traits. Time J Agric Vet Sci 1: 23-30.

[5] Melese T, Negussie R, Etalem T, Rikard L (2015) ( gect of pre Gelatinization on nutritive and non-Nutritive constituents of Taro (Colocasia esculenta L.) Corm. J Nutr Food Sci pp: 1-8.

[6] Van Wyk, B. E. 2005. Food plants of the world: Identification, culinary uses and nutritional value. Briza Publications, Pretoria, South Africa.

[7] Vinning, G. 2003. Select markets for taro, sweet potato and yam. RIRDC Project No. UCQ-13A.

[8] Bose, T. K, Kabir, J, Maity, T. K. Parthasarathy, V. A. and Som, M. G. (2003). Vegetable crops, vol 2. NayaUdyog Publishers, Kolkata. pp: 413-442. 
[9] AsARC (Assosa Agriculture Research Center). 2007. Assosa Agricultural Research Center metrological data for 2007. Assosa, Ethiopia.

[10] Zelalem Ayichew, Tekalign Tsegaw and Nigussie Dechassa. 2009. Response of potato (Solanum tuberosum L.) to different rates of $\mathrm{N}$ and $\mathrm{P}$ fertilization on Vertisol at Debre Berhan, in the central highlands of Ethiopia. African Plant Sci. Journal, 3 (2): 16-24.

[11] SAS (Statistical Analysis System Institute). 2004. SAS statistical guide for personal computers, version 9.0. SAS Institute.

[12] Paul, K. K. and Bari, M. A. (2011). Accession characterization and genetic variability studies in (Colocaisa esculenta (L). Schott). Bangaladesh Journal of Scientific and Industrial Research. 46 (2), pp: 235-242.

[13] Sibyala, S. (2013). Studied the performance of sixteen different taro (Colocasia esculenta (L.) Schott] cultivars for growth, yield and quality parameters. Thesis submitted to
Department of Vegetable Science, Horticulture College and Research Institute, Dr. Y. S. R. Horticultural University.

[14] Angami T., A. K. Jha, Juri Buragohain, Bidyut C. Deka, V. K. Verma and Amit Nath (2015). Evaluation of taro (Colocasia esculenta L.) cultivars for growth, yield and quality attributes. J. Hortl. Sci. Vol. 10 (2): 183-189, 2015.

[15] Elfinesh F., (2008). Processing quality of improved Potato (Solanum tuberosum L.) varieties as influenced by growing environment, genotype and blanching. An M. Sc. Thesis submitted to the school of graduate studies of Haramaya University.

[16] Asmamaw Y., (2007). Postharvest quality of potato (Solanum tuberosum L.) cultivars as influenced by growing environment and storage period. An MSc. Thesis submitted to the school of graduate studies of Haramaya University, 41-44p.

[17] Sarmah, I. 1997. Performance of some colocasia under different spacings. M. Sc. (Agri.) Thesis, AAU, Jorhat, Assam, India. 